\title{
Complex improvement of industrial areas - a requirement for sustainable development of regions nowadays
}

\author{
Maria Vlasova, and Leyla Leonova* \\ Ural Federal University named after the first President of Russia B.N. Yeltsin, Mira Str., 19, 620002 \\ Yekaterinburg, Russia
}

\begin{abstract}
This article provides Russian and foreign experience of successful implementation of projects for redevelopment of industrial zones in large cities. Some projects implemented in Moscow, St. Petersburg are considered in more details. Among foreign projects, the experience of such countries as Great Britain, the USA and China (Hong Kong) should be especially noted. The main goal of the redevelopment of industrial zones in large cities in Russia is to maintain a balance between comfort and convenience for citizens and the interest of investors to give in the implementation of such investment projects. The implementation of projects in the Russian Federation started in 2010. At present, part of the industrial zones in Moscow and St. Petersburg has been almost completely reorganized. Residential complexes, social and cultural facilities, shopping and entertainment centers, roads, parking lots and other infrastructure facilities have been built today instead of industrial zones. In order to meets the requirements of the modern economy, in some cases, industry production has been preserved. The main problems in the implementation of redevelopment projects have been identified, among them are: the absence of the necessary legislation and a clear systemic plan for the reorganization of urban spaces. The authors of the article propose to create a clear concept in Russia for the transformation and redevelopment of industrial areas based on the integrated development of entire residential neighborhoods with all infrastructure facilities, which must be adopted and evaluated with the support of government authorities.
\end{abstract}

\section{Introduction}

Large cities of the world faced with the problem of presence of a great number of unused industrial zones at different stages of their development. Plants and factories fell into decay, warehouses were emptied, some of them need modern environmental protection standards and require modernization. An urban planning solution that meets the challenges of the economy was the renovation of unused industrial areas (zones), the construction of new

* Corresponding author: 1el.leo@mail.ru 
residential and office blocks, public areas on the site of abandoned industrial zones, the creation of centers of science, art, culture and sports.

The development of industry, together with the growing rates of urbanization in cities millionaires of Russia in the second half of the XX century, led to an breakdown of industrial factories and plants in the centers of cities.

Currently, when planning, they seek to move industrial enterprises out of cities. The necessity of the time is the implement an complex approach to the development of settlement territories. The redevelopment of industrial zones is one of the effective mechanisms for the re-profiling them.

\section{Research Methods}

The work used general scientific methods of dialectics, analysis, synthesis, analogy. The methodological basis was the elements of the theory of comparative analysis.

\section{Results and Discussion}

There is a great number of economic and social problems because of the irrational use of the land resources of cities, primarily due to the location of industrial enterprises:

- unfavorable ecological situation,

- high incidence of the population,

- traffic jams,

- low budget revenues from irrational use of the potential of urban lands.

Let's discuss the experience of redeveloping industrial areas in Moscow. The "rusty belt" of Moscow began to grow in the XVII century, when the Armory Chamber and the Cannon Yard were launched. A hundred years later, a large number of glass, textile and paper enterprises opened in the city, for example, the Khamovny Dvor, a large workshop in the XVIII century. In the XIX and early XX centuries, along with the development of industry in Moscow, the number of corresponding factories began to grow rapidly: in 1916, the auto giant ZIL appeared, in the 1930s, many artels and metalworking, metallurgy and mechanical engineering enterprises were opened [1].

In Soviet times in the USSR, the development of large industries continued. They thought that the presence of a large number of industrial zones within the city and the central part of the city was a sign of progress. Ultimately, the area of Moscow's industrial zones in 2014 amounted to 18.8 thousand hectares, which is almost $17 \%$ of the city's territory within the old borders. In total, there were 83 production and communal zones in Moscow. It should be noted that about a great part of such zones were not used for their functional purposes. The largest industrial zones of the capital at that time included such enterprises as ZIL, AZLK, Moskvich, Serp and Molot, Verkhniye Kotly, Nagatinsky Zaton, the former Tushinsky airfield, etc.

Before starting for a more detailed description of the measures implemented within the framework of the Moscow redevelopment, it is worth noting that in world practice there is no experience of renovating such large-scale industrial areas.

Purposeful work with the industrial zones of Moscow began only in 2010. As part of the redevelopment of depressed areas, the urban planning policy of the capital is characterized by active work aimed at reducing administrative barriers in construction, which include procedures related to the registration of rights to a land plot, obtaining a construction permit, etc. The basis of projects for the renovation of industrial zones is their integrated development, which primarily consists not only in the construction of profitable housing 
from a commercial point of view, but also in the creation of high-quality infrastructure, social and cultural - entertainment facilities, new jobs and recreation areas for Muscovites [2].

The construction of a total of 451 real estate objects on the former industrial territories, with a total area of 10.2 million square meters., about a third of this volume is occupied by housing was the result of the first six years of the project for reformatting industrial zones in Moscow. [3, 4].

One of the successful examples of working with industrial areas is the complex improvement of the Moscow are the Cardboard and Printing Plant. On the site of a former industrial zone with an area of 130,000 sq. m. now there is a club quarter "AFI Paveletskaya", consisting of three residential buildings of variable number of stores, designed for 520 apartments and 220 apartments. From an architectural point of view, the construction project is interesting because, in addition to create the modern look of the new district, the developer also preserved the architectural elements of the late 19th century, which included several buildings of the cardboard factory of the merchant EE Shlikhterman [5].

One of the most ambitious projects characterizing the "Moscow" approach to the redevelopment of industrial zones is the development of the territory of the former Likhachev plant ("ZIL"). The renovation of ZIL is an example of a complex development, when developers want not only to benefit, but also to create comfortable living conditions for the population. The total building area of the former plant is about 5.2 million square meters, of which 2.7 million sq. m. is reserved for housing [6].

According to the project of reconstruction of the ZIL territory, part it is occupied by a sports and entertainment district. Today the Ice Palace with three arenas, the Water Sports Palace, which houses the Synchronized Swimming Center and the Water Entertainment Center with fitness, have already been built. In addition to the above, the Hockey Museum and the creation of infrastructure for servicing professional sports events - a business center and a complex of apartments - have been designed too.

In addition to the above, about $30 \mathrm{~km}$ of roads will be equipped on the area of ZIL. The construction of motorways is also planned both on the territory of the plant and in future residential areas. New bridges across the Moskva River will become additional "links" between the ZIL territory and the city. Additionally, the construction of a road bridge has been planned, which will help connect the Third Transport Ring and the Varshavskoe Highway. All reconstruction will be completed by 2025. [6]

The main goal of the program for the reorganization of Moscow's industrial zones is to strike a balance between comfort and convenience for citizens and the desires of investors. Within the framework of the program, part of the industrial zones is supposed to be completely reorganized, by building in their place residential areas, social facilities, roads, parking lots and other infrastructure, in others - to preserve production. The policy chosen by the city authorities contributes to the emergence of an economic effect, which is achieved primarily through the creation of a large number of jobs, which provides the city with additional budget revenues.

The Center for Contemporary Art is another example of the complex development of the territory of a former Moscow Grape and Dessert Wines Combine, built back in 1889 [7].

And although the results of the program of redevelopment of industrial zones of the city of Moscow are still intermediate, it should be noted that in the period from 2011 to 2017, 8.77 million square meters were built. m. In 2017, 1.9 million square meters were commissioned. m., of which 0.8 million sq. m. of housing, 6 social facilities were built in these territories. [2-5] 
Another large metropolis, St. Petersburg, has its own characteristics. St. Petersburg is a large city with historically developed areas of industrial development and industry specificity. Since its inception, the city has been established as an industrial center.

Thus, in the history of St. Petersburg there was a period when production facilities were located in the central part of the city, along the Neva River. In the first third of the 18th century, large industrial enterprises were created in St. Petersburg, such as the Admiralty in 1704, the Kronverkskaya shipyard, the Izhora plant, the Sestroretsk plant, the Particular shipyard, the Liteiny and the Cannon yard, the Shpalernaya manufactory, the Peterhof lapidary factory, the Galernaya shipyard, the Porokhovoy greenery factory, tannery Isaev. The main feature of the location of industrial enterprises was the preferred location of the plant near water in order to use it. Among the other things, there was a stage in the history of the northern capital when the "southern industrial belt" was built up, running from the Neva River to the southern coast of the Gulf of Finland.

Today, a new industrial belt is being formed, located along the ring road and the border of the city and the region. Currently, the "gray belt" of St. Petersburg occupies a significant part of the city. For example, in an average European city, industrial enterprises account for about $10 \%$ of the total area, and in St. Petersburg, the location of the "gray belt" accounts for more than $40 \%$ of the central part [8].

In December 2004, the Government of St. Petersburg adopted the Program for the Development of Industrial, Public, Business and Warehouse Territories, which divided the industrial zones of the city into two groups:

1) Industrial zones with further industrial use and development;

2) Industrial zones subject to urban transformation, change in the nature of land use [9].

By the beginning of 2010 the area of industrial territories of St. Petersburg in comparison with the indicators of 2004 decreased by slightly less than $9 \%$. During this period, some significant in the past for St. Petersburg enterprises, which include the factories "Krasny Triangle", "Russia", "Krasnoe Znamya", completely stopped their activities.

The renovation of the P. Alekseev weaving factory can be considered a successful project of the St. Petersburg redevelopment. The building was built in 1851 and used as a paper mill. With the beginning of perestroika, the factory has been stopped and for a long time the building was ownerless, so part of the buildings have been collapsed. In 2001, the complex was taken under protection and recognized as a cultural heritage site. In 2010, the Tkachi creative space project was adopted. Today, the modern showrooms, shops, photo studios, design agencies, fashion shows, concerts, educational seminars and master classes are located there.

The most unusual of the existing redevelopment projects in St. Petersburg is considered to be the project implemented on the embankment of the Admiralty Canal "New Holland Island". The project is extraordinary because it is the most famous man-made island in St. Petersburg. In Soviet times, the warehouses of the Leningrad naval base were located here. In 2004, a competition for reconstruction was announced, but the real work began only closer to 2010. According to the proposed project, a former commandant's house and a smithy were opened on the island, where a club and a restaurant work nowadays. In summer, city-wide festivals, music concerts, master classes are held on the island, and in winter an ice rink is opened. In the center of the island there is a virtually life-size model of the frigate "Peter and Paul", on the basis of which there is a children's playground [10].

Over the past 7 years, more than 4 million square meters have been built in the former industrial zones of St. Petersburg. By 2020, it is planned to build almost 3 million square meters housing on the former factory land. Today the leaders in terms of the scale of 
redevelopment in St. Petersburg are Kalinsky (844 thousand sq. m.), Nevsky (787 thousand sq. M.) And Moskovsky (709 thousand sq. m.) Districts. [7-9]

From 1972 to 1981, about 550 enterprises were moved out from the central part London. On the vacated areas, the authorities implemented new construction, creating residential and office quarters, building new roads, as well as cultural objects. For example, the famous Tate Modern gallery of contemporary art is located in the premises of a former power plant.

A striking example of the redevelopment of an industrial zone in London is the Docklands area, which appeared on the site of one of the world's largest ports, the first docks of which were built at the end of the 17th century. The port was in demand until 1960 of the XX century, however, by that time, cargo began to transport large-sized vessels, which the port could no longer accommodate. In the 1970s, the docks finally closed. Especially for the modernization of the area with a total area of $22 \mathrm{sq}$. km. In 1981, the government created the Docklands Development Corporation. For the implementation of the redevelopment project, the corporation used two schemes - "greenfield" and "brownfield". The "greenfield" scheme involved the creation of investment sites on an undeveloped and unsecured plot of infrastructure, "brownfield" - work with previously existing sites, provided with infrastructure and facilities, in respect of which reconstruction or major repairs are being carried out [11].

After the work in the Docklands, an area with cheap real estate and developed infrastructure was created, which became interesting for businesses and residents. Docklands became a new center of business activity of the city, and the Canary Wharf quarter located within its borders acquired the status of the second financial center of London [12].

The slowdown in economic growth in the United States in the late 1980s led to the bankruptcy of many industrial enterprises in the country. The territories of the former factories fell into decay, while the ecological situation made them uninhabitable.

In order to rebuild the territories, in 1994, the Clinton administration adopted a program aimed at developing the territories of the former industrial zones, the so-called "brownfields". It enabled states, cities, local communities, and other stakeholders to work together to assess, safely clean up, and sustainably develop brownfields. State support introduced special grants from the federal government that could provide a state, city or enterprise with a grant of up to $\$ 1$ million, depending on the size and significance of the project. In addition, from 1997 to 2011, there were tax incentives in the country for enterprises wishing to develop former industrial territories.

One of the most significant and illustrative projects in terms of local community development is the invest project of two neighboring cities - Ranson and Charles Town. In the 1990s, both Charles Town and Ranson manufacturing centers began to lose jobs. At that time, one of the world's largest factories - a manufacturer of vending machines, a foundry and a metal warehouse were located there. When these enterprises were closed, the city lost about a quarter of the revenues that went to the budget. In this regard, huge areas of territories contaminated with hazardous substances were formed.

The transformation of depressive zones began in 1999. An initiative called the Commercial Corridor was formed, which was a project to develop a 1.5 mile (approximately $2.4 \mathrm{~km}$ ) stretch connecting Ranson and Charles Town. In the period from 2001 to 2010 , the cities received several grants worth more than $\$ 700,000$. The funds raised were used to research and assess the degree of contamination of the territories, as well as to create a comprehensive development plan for all brownfields. In addition to the above, cities received funding in the form of grants and loans under other federal programs for the recovery of the US economy about $\$ 11.5$ million. 
The former Maytag paint factory, out of service since 1989, was one of the first sites to be explored under the program for further cleaning. Today the former industrial area is a popular public space among residents and tourists. It hosts sports events, city fairs, as well as numerous exhibitions and conferences [13].

The US Federal Brownfield Redevelopment Program was not limited to the above example. As of the end of 2015, the United States managed to restore more than 23 thousand plots, create 108 thousand jobs, attract \$20.96 billion and clean up 24 thousand hectares of territories for further development $[13,114]$.

After the Second World War the active development of industry began in China, including Hong Kong. From 1950 to 1980, manufacturing activities became the main sector of Hong Kong's economic development. Since the late 1980s, as a result of the intensification of China's reform and opening-up policy, Hong Kong's industry has gradually shifted to mainland China, and the city itself has turned into a financial center.

In May 2001, the Department of Redevelopment was created in Hong Kong, which began its activities with the development of an urban development plan for the city, including taking into account the increase of industrial territories. The result of the Department's work is the city's redevelopment policy program.

Today, almost all major industrial zones in Hong Kong are experiencing a "rebirth". For example, in the Juan Wan area, located on the coast of the Rambler channel, there were previously a Texas oil depot, as well as factories for bottling soda water, dyeing fabrics, weaving - a spinning mill, a flour factory, etc. As the manufacturing industry declines industrial buildings in this area gradually turned into commercial ones. At present, this territory houses a 41-storey office center "Cable TV Tower" with a height of $197 \mathrm{~m}$, in which the headquarters of the largest cable operator in the city "Cable TV Hong Kong" is based [15].

One of the most significant redevelopment projects in Hong Kong can be called as the project to reform the territory of "Kun Tong" - in the past the largest industrial zone of the Kowloon Peninsula. In the process of redevelopment of the Kunthon territory, a project was implemented to build a large business complex Millennium City with 367 thousand sq. m. office space and 67 thousand square meters. - trading centers.

In March 2007, the Department initiated a new plan. The idea was to "renovate" the Yu Min Fang residential area, where workers employed in local industries lived in five-story buildings since the early 1970s. This project became the largest in the history of the Department, total investments amounted to $\$ 7.5$ billion, the area of the territory - 63 thousand square meters. In addition, in the course of the transformations, it is planned to preserve the historical appearance of about 18 thousand square meters. of the territory [15, $16]$.

The direction of redevelopment of industrial zones originated in Russia recently, therefore there are many problems associated with the implementation of projects for the development of industrial territories, among them there are the following problems, associated with:

- conversion of objects,

- registration of rights to a land plot,

- transfer from federal to private ownership of bomb shelters,

- maintaining the ecological cleanliness of the site,

- transfer of property rights,

- high risks for developers,

- transport and infrastructure facilities,

- legislation in the field of redevelopment of industrial zones, etc. 
The identified problems are typical for all large cities of the Russian Federation [17, $18]$.

In this regard, there is a question, is it possible to apply the accumulated foreign and Russian experience of redevelopment of industrial territories in large cities of Russia, and to what extent?

\section{Results and Conclusion}

The authors of the article believe that for the successful implementation of redevelopment projects in Russia, based on the data of successful experience, the following recommendations should be given:

1. The development of industrial zones must be carried out as projects formalized in the form of a municipal redevelopment plan.

2. Adoption in Russia of the necessary legislative acts defining the procedure for the application of redevelopment.

3. The main thing is the creation in Russia of a concept for the transformation of industrial zones based on the principles of integrated development of territories.

4. Creation of a reliable database and information on the scale of the transformation process of former industrial territories in large cities of Russia as a result of redevelopment.

5. State support and partial financing of such redevelopment projects, possible in the format of implementing a PPP (Private and Powerful Partnership) mechanism, since redevelopment projects are expensive and difficult to implement from a technical and legal point of view.

\section{References}

1. E. Ogorodnikov, Expert, 18/19, 40 (2019)

2. T.A.Vasilyeva, V.A. Lunyakov, Economy and entrepreneurship, 4, 960 (2017)

3. Research "Moscow RE: industrial, Typology of production areas and the best practices of redevelopment ", https://www.centeragency.org/ru/

4. Redevelopment of industrial zones in Moscow: Professional magazine, 3 (14), 28, (2016)

5. Internet portal: Complex of urban planning policy and construction of the city of Moscow, https://stroi.mos.ru/news/

6. Official portal of the Mayor and the Government of Moscow (2016), https://investmoscow.ru/

7. Winzavod Center for Contemporary Art, http: //www.winzavod.ru/history/

8. Official site: Network edition of the newspaper "Komsomolskaya Pravda" (2017), https://www.kp.ru/

9. Official site of the Government of St. Petersburg: Committee for Urban Planning and Architecture, http: //kgainfo.spb.ru/

10. Official site: New Holland Space, http://www.newhollandsp.ru/

11. Development and Redevelopment (2017), http://articles.latimes.com

12. M. Bujold, Real Estate Issues, 38 (1) (2013)

13. S. Nwachukwu, American journal of social and management sciences, 2 (1) (2011) 
14. R.B. Preiser, Urban Land, 7 (2015)

15. Lin Yifu, Chinese miracle: development strategy and economic, 367 (2001)

16. Pi Qiansheng Experience of Chinese Zones of Techno-Economic Development, 486 (2006)

17. Professional Real Estate Development: ULI Business Guidelines, 289 (2015)

18. Production management in construction: Textbook, 297 (2016) 